\section{Biological and Mechanistic Activities of Phenazine Antibiotics Produced by Culture LL-14I352}

\author{
Maya P. Singh*, Ana T. Menendez ${ }^{\mathrm{a}, \boldsymbol{\eta}}$, \\ Peter J. Petersen ${ }^{b}$, Wei-Dong Ding, \\ William M. Maiese and Michael Greenstein
}

Natural Products, ${ }^{\mathrm{b}}$ Infectious Diseases and a Anticancer Research Sections, Wyeth-Ayerst Research, Pearl River, New York, 10965 U.S.A.

(Received for publication June 30, 1997)

In the course of screening microorganisms isolated from the marine environment, fermentation samples of culture LL-14I352 were found to exhibit activity in the Biochemical Induction Assay (BIA), which detects agents that directly or indirectly initiate DNA damage ${ }^{1)}$. This culture was originally isolated from an orange tunicate collected from the Pacific Ocean in proximity to Fiji and was subsequently identified as a new halophilic marine bacterium $^{2)}$. The BIA-active compounds isolated from fermentations of this culture were found to be the new phenazine antibiotics LL-14I352 $\alpha$ and $\beta$, which also exhibited activity in both our antibacterial and antitumor primary screens. Coincidently, a compound identical to LL-14I352 $\alpha$, pelagiomicin-A, was also discovered from a marine bacterium isolated from a different marine environment by IMAMURA et al. ${ }^{3)}$. We identified an additional component, LL-14I352 $\beta$, which was found to be less active than the $\alpha$ component. Further details of in vitro and in vivo antibacterial, cytotoxic, and antitumor activities and the mechanism of antibacterial action are reported here.

The in vitro antibacterial activities against 15 Gram- positive and 5 Gram-negative isolates were determined by the broth microdilution method ${ }^{4)}$. LL-14I352 $\alpha$ exhibited good Gram-positive activity (MIC, $0.25 \sim 2$ $\mu \mathrm{g} / \mathrm{ml}$ ), but moderate to poor Gram-negative activity (MIC, $16 \sim>128 \mu \mathrm{g} / \mathrm{ml}$ ). This data is consistent with the activities reported for pelagiomicin $A^{3)}$. LL-14I352 $\beta$, which lacks the amino acid residue (see Fig. 1), was approximately 40-fold less active (Gram-positive MIC, $8 \sim>64 \mu \mathrm{g} / \mathrm{ml}$ ) than the $\alpha$ component. The amino acid residue of the LL-14I352 $\alpha$ may be facilitating its

Fig. 1. Structure of LL-14I352 $\alpha$ and related compounds. LL-14I352 $\alpha$ is identical to pelagiomicin A.<smiles>O=C(O)c1cccc2nc3c(Br)ccc(Br)c3nc12</smiles>

Compound $\quad \mathrm{R}_{1}$

Table 1. Inhibitory effects of LL-14I352 $\alpha$ and known antimicrobial agents on incorporation and uptake of radiolabeled precursors in E. coli imp.

\begin{tabular}{|c|c|c|c|c|c|c|c|}
\hline \multirow{3}{*}{ Compound } & \multirow{3}{*}{$\begin{array}{l}\text { Conc. } \\
(\mu \mathrm{g} / \mathrm{ml})\end{array}$} & \multicolumn{6}{|c|}{ Inhibition ( $\%$ of untreated control) } \\
\hline & & \multicolumn{2}{|c|}{${ }^{3} \mathrm{H}-\mathrm{Tdr}$} & \multicolumn{2}{|c|}{${ }^{3} \mathrm{H}-\mathrm{Udr}$} & \multicolumn{2}{|c|}{${ }^{3} \mathrm{H}-\mathrm{AA}$} \\
\hline & & Incorp & Uptake & Incorp & Uptake & Incorp & Uptake \\
\hline LL-14I352 $\alpha(2 \times \mathrm{MIC})$ & 1 & 94 & 37 & 53 & -3 & 16 & 19 \\
\hline (MIC) & 0.50 & 87 & 32 & 40 & -6 & 4 & 19 \\
\hline$(1 / 2 \times \mathrm{MIC})$ & 0.25 & 82 & 29 & 18 & 5 & -2 & 33 \\
\hline Ciprofloxacin & 0.25 & 87 & 43 & 7 & -3 & 15 & -5 \\
\hline Rifampin & 0.25 & 10 & -59 & 97 & 54 & 63 & 9 \\
\hline Chloramphenicol & 8 & 10 & -12 & 8 & -9 & 84 & 55 \\
\hline Polymyxin B & 8 & 99 & 97 & 98 & 93 & 97 & 78 \\
\hline
\end{tabular}

Data presented represents 5 minutes pretreatment and 5 minutes pulse labeling. Incorp $=$ radiolabeled precursor incorporated into TCA-precipitable material. Uptake = total radiolabeled precursor remaining in the cells after an instant saline wash.

† Present address: Bristol-Myers Squibb Company, P. O. Box 4500, Princeton, NJ 08543 
transport through the cytoplasmic membrane. The phenazine-type antibiotics (DOB-41 and DC-86-M) isolated from a Streptomyces sp. ${ }^{5)}$ and a Pseudomonas sp. ${ }^{6)}$ have also been reported to exhibit superior Gram-positive activity. LL-14I352 $\alpha$ exhibited good activity (MIC/MBC, $0.5 / 2 \mu \mathrm{g} / \mathrm{ml}$ ) against $E$. coli carrying an imp outer membrane mutation, but poor activity against wild type $E$. coli suggesting a permeability problem with this compound. MICs increased two-fold with 100 -fold increase in inoculum density, and the effect was bactericidal (MBC was only $1 \sim 2$ fold higher than MIC). LL-14I252 $\alpha$ did not appear to bind to DNA or serum as the addition of exogenous DNA $(200 \mu \mathrm{g} / \mathrm{ml}$ of herring sperm or calf thymus) or horse serum $(4 \% \mathrm{v} / \mathrm{v})$ into the medium did not affect activity against $E$. coli imp. The MIC of adriamycin (a known DNA-binding agent) increased 8-fold in presence of DNA, and the presence of horse serum considerably reduced the antibacterial activity of pyroindomycin, a known serum-bound antibiotic (data not shown).

Inhibition of DNA, RNA, and protein synthesis were determined by measuring the incorporation of the radiolabeled precursors ${ }^{3} \mathrm{H}-\mathrm{Tdr},{ }^{3} \mathrm{H}-\mathrm{Udr}$, and ${ }^{3} \mathrm{H}-\mathrm{AA}$, respectively, into TCA-precipitable material prepared from logarithmic-phase cultures of E. coli imp ${ }^{4}$. Within 5 minutes of treatment with $1 / 2 \times$ MIC of LL-14I352 $\alpha$, DNA synthesis was inhibited by $82 \%$, whereas RNA and protein syntheses were only marginally affected (Table 1). During the same period, the control drugs ciprofloxacin, rifampin, and chloramphenicol predominantly inhibited DNA, RNA and protein synthesis, respectively. Polymyxin B inhibited incorporation into all three macromolecules. The concentrations of LL-14I352 $\alpha$ required for $50 \%$ inhibition $\left(\mathrm{IC}_{50}\right)$ of DNA, RNA, and protein syntheses within 10 minutes $(5$ minutes preincubation with drug and 5 minutes pulse labeling) were $0.10,0.84$, and $2.70 \mu \mathrm{g} / \mathrm{ml}$, respectively (Fig. 2). After 15 minutes, the $\mathrm{IC}_{50} \mathrm{~s}$ for protein synthesis decreased to $1.40 \mu \mathrm{g} / \mathrm{ml}$, whereas the $\mathrm{IC}_{50} \mathrm{~s}$ for DNA and RNA syntheses remained almost unchanged at 0.12 $\mu \mathrm{g} / \mathrm{ml}$ and $0.80 \mu \mathrm{g} / \mathrm{ml}$, respectively (data not shown). Although inhibition of the various macromolecular processes was concentration dependent, DNA synthesis was preferentially inhibited at all concentrations. The effect of drugs on the cellular uptake of radiolabeled precursors was determined by measuring radioactivity retained in saline-washed cells under the same experimental conditions. For each drug tested, uptake of the three radiolabeled precursors was unaffected relative to the specific inhibition of incorporation into TCAprecipitable material (Table 1). BIA activity of LL$141352 \alpha$ at a concentration as low as $0.08 \mu \mathrm{g} /$ spot further confirmed its DNA-damaging activity in bacteria.

Fig. 2. Effects of LL-14I352 $\alpha$ on macromolecular synthesis in E. coli imp.

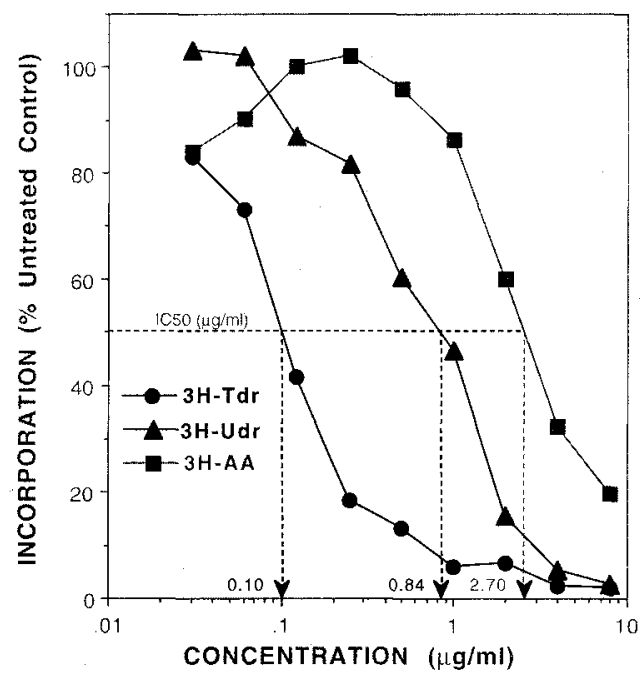

Exponential-phase cells were treated with various concentrations of the drug for 5 minutes and were then pulselabeled for 5 minutes with ${ }^{3} \mathrm{H}-\mathrm{Tdr},{ }^{3} \mathrm{H}-\mathrm{Udr}$, or ${ }^{3} \mathrm{H}$-AA for measuring DNA, RNA, or protein synthesis, respectively. The arrows indicate the $\mathrm{IC}_{50} \mathrm{~s}$ (concentrations at which incorporation was inhibited by $50 \%$ ) for each macromolecular process.

Table 2. In vitro cytotoxic activity $\left(\mathrm{IC}_{50}, \mu \mathrm{g} / \mathrm{ml}\right)$ of $\mathrm{LL}-\mathrm{I} 4 \mathrm{I} 352$ antibiotics against selected human tumor cell lines.

\begin{tabular}{|c|c|c|c|c|}
\hline Cell name & Tumor type/Properties & LL- $141352 \alpha$ & LL-14I352 $\beta$ & Adriamycin \\
\hline $\mathrm{A} 2780 \mathrm{~S}$ & Ovarian/solid & 0.18 & 0.74 & 0.004 \\
\hline A2780DDP & $\begin{array}{l}\text { Ovarian/solid/DNA damaging agent } \\
\text { resistant }\end{array}$ & 0.60 & 6.30 & 0.05 \\
\hline SW620 & Colon/solid/MDR drug sensitive & 0.53 & 1.80 & 0.09 \\
\hline MIP & Colon/solid/MDR drug resistant & 0.61 & 0.84 & 1.00 \\
\hline CCRF-CEM & $\begin{array}{l}\text { T-cell leukemia/suspension/MDR drug } \\
\text { sensitive }\end{array}$ & 0.70 & 6.90 & 0.05 \\
\hline NEC & $\begin{array}{l}\text { Normal endothelial cell/solid/MDR } \\
\text { drug sensitive }\end{array}$ & 2.70 & 7.30 & 0.008 \\
\hline
\end{tabular}

Method: Kubota et al. Colorimetric chemosensitivity testing using sulforhodamine B. J. Surgical Oncology $52: 83 \sim 88,1993$. 
Bleomycin, a known DNA-damaging agent, gave a positive BIA response at a minimum concentration of $0.003 \mu \mathrm{g}$ per spot.

Since LL-14I352 $\alpha$ and $\beta$ were found to be BIA active and to inhibit preferentially DNA synthesis, they were tested for cytotoxicity against five human tumor cell lines with defined properties and against a normal bovine cell line (Table 2). Other phenazines isolated from diverse sources have been found to exhibit antitumor activity ${ }^{7,8}$. The mean $\mathrm{IC}_{50}$ values for $\mathrm{LL}-14 \mathrm{I} 352 \alpha$ and $\beta$ were $0.88 \mu \mathrm{g} / \mathrm{ml}$ and $3.98 \mu \mathrm{g} / \mathrm{ml}$, respectively, suggesting that the $\alpha$ component is 4.5 times more cytotoxic than the $\beta$. The presence of the amino acid residue in the $\alpha$ component may be facilitating its entry into the cells (Fig. 1). The ratio of the $\mathrm{IC}_{50}$ value for A2780DDP, a cell line with enhanced DNA repair capability, to that of its parent $\mathrm{A} 2780 \mathrm{~S}^{9)}$ for adriamycin, LL-14I352 $\beta$, and LL-141352 $\alpha$ were $12.5,8.5$, and 3.3 , respectively. These data suggest that the $\alpha$ component is less responsive to the enhanced DNA repair capability of A2780DDP. Antibiotic LL-14I352 $\alpha$ and $\beta$ were equipotent against a MIP multidrug-resistant colon carcinoma cell line and SW620, a comparable drug-sensitive line, suggesting that these compounds are unaffected by the $p$-glycoproteinmediated drug efflux pump ${ }^{10 \sim 12)}$. LL-14I352 $\alpha$ appeared to be somewhat more active against the tumor cell lines than against the normal endothelial line.

LL-14I352 $\alpha$ and LL-14I352 $\beta$ were inactive in an in vivo P388 murine leukemia model at concentrations up to $8 \mathrm{mg} / \mathrm{kg}$. Pelagiomicin A also was inactive against P388 in in vitro testing ${ }^{3)}$. Testing has not been conducted, however, in solid tumor models. Acute toxicity was observed at $16 \mathrm{mg} / \mathrm{kg}$. LL-14I352 $\alpha$ and $\beta$ also failed to protect mice against a lethal $S$. aureus infection at doses up to $8 \mathrm{mg} / \mathrm{kg}$. The $\mathrm{LD}_{50}$ for LL-14I352 $\alpha$ was estimated to be $16 \mathrm{mg} / \mathrm{kg}$, but the $\beta$ component exhibited no toxicity at doses up to $32 \mathrm{mg} / \mathrm{kg}$. Lack of in vivo activity and a poor toxicological profile would most likely limit the therapeutic usefulness of LL14I352 $\alpha$.

\section{References}

1) Greenstein, M.; M. J. Wildey \& W. M. Maiese: The biochemical induction assay and its application in the detection of the calicheamicins. In Enediyne Antibiotics as Antitumor Agents. Ed., D. B. Borders \& T. W. DOYLE, pp. $17 \sim 27$, Marcel Dekker Inc, NY, 1993

2) Bernan, V. \& D. A. Montenegro: Personal communication

3) Imamura, N.; M. Nishijima, T. Takadera, K. Adachi, M. SAKaI \& H. SANO: New anticancer antibiotic pelagiomicin, produced by a new marine bacterium Pelagiobacter variabilis. J. Antibiotics 50: 8 12, 1997

4) Singh, M. P.; P. J. Petersen, N. V. Jacobus, W. M. Maiese, M. Greenstein \& D. A. SteinberG: Mechanistic studies and biological activity of bioxalomycin $\alpha_{2}$, a novel antibiotic produced by $S$. viridodiastaticus subsp. "litoralis" LL-31F508. Antimicrob. Agents Chemother. 38: $1808 \sim 1812,1994$

5) Takahashi, K.; I. TaKahashi, M. Morimoto \& F. TomitA: DC-86-M, a novel antitumor antibiotic II. Structure determination and biological activities. J. Antibiotics 39: $624 \sim 628,1986$

6) Shoji, J.; R. Sakazaki, H. Nakai, Y. Terui, T. Hattori, O. Shiratori, E. Kondo \& T. KonISHI: Isolation of a new phenazine antibiotic, DOB-41, from Pseudomonas species. J. Antibiotics 41: 589 594, 1988

7) Nakaike, S.; T. Yamagishi, K. Nanaumi, S. Otomo \& S. Tsukagoshi: Cell-killing activity and kinetic analysis of a novel antitumor compound NC-190, a benzo $[a]$ phenazine derivative. Jpn. J. Cancer Res. 83: 402 409, 1992

8) Tarui, M.; M. Doi, T. Ishida, M. Inoue, S. NakaIKe \& K. KitAmURA: DNA-binding characterization of a novel anti-tumor benzo $[a]$ phenazine derivative $\mathrm{NC}$-182: spectroscopic and viscometric studies. Biochem. J. 304: $271 \sim 279,1994$

9) Pratesi, G.; M. Tortereto, C. Corti, R. Giardini \& F. ZuNINO: Successful local regional therapy with topotecan of intraperitoneally growing human ovarian carcinoma xenografts. British J. Cancer 71: 525 528, 1995

10) Alvarez, M.; K. Paull, A. Monks, C. Hose, J. S. Lee, J. Weinstein, M. Grever, S. Bates \& T. Fojo: Generation of a resistance profile by quantitation of $\mathrm{mdr}-1 / \mathrm{p}$ glycoprotein in the cell lines of the National Cancer Institute Anticancer Drug Screen. J. Clin. Invest. 95: 2205 2214, 1995

11) ChIN, K. V. \& B. LiU: Regulation of the multidrug resistance (MDR1) gene expression. In Vivo 8: 835 841, 1994

12) Zhang, X. P.; M. K. Ritke, J. C. Yalowich, M. L. Slovak, J. P. Ho, K. I. Collins, T. Annable, R. J. Arceci, P. E. Durr \& L. M. Greenberger: P-glycoprotein mediated profound resistance to bisantrene. Oncology Research 6: $291 \sim 301,1994$ 